\title{
The blurred line between photic and aphotic environments: a large Mexican cave with almost no dark zone
}

\author{
Luis M. Mejía-Ortíz ${ }^{1}$, Tanja Pipan², David C. Culver ${ }^{3 *}$, and Peter Sprouse ${ }^{4}$ \\ ${ }^{1}$ Lab. de Bioespeleologia y Carcinologia, División de Desarrollo Sustentable, Universidad de Quintana Roo, C.P. 77640, Cozumel, Mexico \\ ${ }^{2}$ Karst Research Institute at the Research Centre, Slovenian Academy of Sciences and Arts, Titov trg 2, SI-6230, Postojna, Slovenia \\ ${ }^{3}$ Department of Environmental Science, American University, 4400 Massachusetts Ave. NW, Washington, DC 20016, USA \\ ${ }^{4}$ Zara Environmental LLC, 1707 West FM 1626, Manchaca, TX 78652, USA
}

\begin{abstract}
Sistema Muévelo Rico is a $1.2 \mathrm{~km}$ long cave in Quintana Roo, less than $2 \mathrm{~km}$ from the Caribbean Sea. We measured illuminance to a level of 0.1 lux, organic matter (weight loss on ignition), temperature, and relative humidity. The last two were measured at hourly intervals for nearly one year. Approximately one-third of the cave has illuminance values greater than 0.01 lux, and most of the rest of the cave has light as well. Temperature and relative humidity were relatively constant, but they showed a daily cycle at all stations, albeit with different strengths. Organic matter averaged $8 \%$, intermediate in value between surface and aphotic zones. Both eyeless species and eyed predators occurred throughout the cave. Their occurrence can best be explained by their foraging for organic matter and incurring an increased risk of predation.
\end{abstract}

Keywords: $\quad$ cave environments, eogenetic karst, light as an ecological factor, troglomorphy, twilight

Received 9 October 2017; Revised 29 November 2017; Accepted 29 November 2017

Citation: $\quad$ Mejía-Ortíz L.M., Pipan T., Culver D.C. and Sprouse P., 2018. The blurred line between photic and aphotic environments: a large Mexican cave with almost no dark zone. International Journal of Speleology, 47 (1), 69-80. Tampa, FL (USA) ISSN 0392-6672 https://doi.org/10.5038/1827-806X.47.1.2155

\section{INTRODUCTION}

All of life dwelling on the Earth's surface is attuned to the daily light-dark cycle. In this cycle, light is present throughout the night, and many species adapt to the low light of dawn, dusk, and night (Johnsen, 2012). These adaptations typically include modifications to eye structure and function that increase visual acuity in dim light (Kelber et al., 2002; Tierney et al., 2017), and the evolution of echolocation in bats and some birds. Even more fundamentally, the light-dark cycle entrains the circadian clock, which in turn regulates physiological functions.

Even more profound is the complete absence of light in habitats such as caves, deep soil, turbid freshwater rivers, termite mounds, and other aphotic habitats (Culver \& Pipan, 2014; Fenolio, 2016). Adaptations to total darkness are more extreme. The most common aphotic environment, or more properly an aphotic environment in the absence of bioluminesnce, is the deep sea. The widespread occurrence of bioluminescent organisms in the ocean depth, evolved for species and sex recognition, predation, and predation avoidance (Johnsen, 2012; Fenolio, 2016), is testament to the power of the absence of light as a selective force. Cave life is best known for the nearly universal occurrence of blindness (or extreme eye reduction) and pigment loss (or reduction), features often found in inhabitants of other aphotic environments (Fenolio, 2016). While many cave dwelling species retain a functional circadian clock (Friedrich, 2013), how it operates in darkness remains a puzzle.

Caves have a transition zone with respect to light, one that mimics that transition from day to night on the Earth's surface. Unlike the daily cycle of light and dark, which is well characterized with respect to light during the night (Johnsen et al., 2006; Johnson, 2012), the transition from light to dark at the entrance to a cave is not well described, nor is it considered of particular importance because of the relatively abrupt transition to total darkness. Typically, the transition zone is short (only a few meters) and there is in fact a distinct fauna of the twilight zone of cave entrances, one that is dominated by groups that are not found in the aphotic zone of caves, such as frogs (Graham, 1962) and moths (Graham, 1968; Taylor et al., 2010).

The fauna of the aphotic zone is distinct. The most common feature of the inhabitants of caves and other aphotic subterranean environments is that they typically harbor species with morphological 
characteristics that only make sense in aphotic environments (Mejia-Ortiz, 2005; Culver \& Pipan, 2009). Most prominent among these subterranean associated features are the loss of eyes and pigmentation, and increased extra-optic sensory structures. These dark zone specialists are highly vulnerable to eyed surface-dwelling predators, and perhaps to UV radiation (Fišer et al., 2014). Nearly all such specialists (termed troglomorphs by Christiansen (1962) are limited to aphotic environments, with a few exceptions that are sink populations (Trajano \& de Carvalho, 2017), populations in decline in the absence of immigration (Pulliam, 1988).

Subterranean (aphotic) habitats, including noncave habitats such as the underflow of rivers (Malard et al., 2000), talus slopes (Růžička, 1990), and groundwater aquifers (Longley, 1984), have reduced annual and daily fluctuations in temperature, relative humidity, and other environmental parameters (e.g., Eigenmann, 1909; Pipan et al., 2011). This relative constancy of the environment may also be a selective factor in the evolution of subterranean species, especially in having to cope with the absence of daily cycles (Poulson, 1963). Howarth (1980) argues that relative humidity itself is an important selective factor and a factor that isolates animals in caves because of cuticular thinning. More generally, reduced organic matter and nutrients have been invoked as important selective factors in the evolution of reduced metabolic rate (Hüppop, 2000), foraging behavior (Bilandžija et al. 2013), and increased egg size (Rouch, 1968). However, Pipan and Culver $(2012,2015)$ argue that the dominant selective force that differentiates surface and subterranean environments is the presence or absence of light.

There are of course many dimly lit (twilight) habitats such as soil, leaf litter and deep aquatic habitats. Light very rapidly declines in soil, with less than $99 \%$ of light remaining after one mm (Ciani et al., 2005). Light penetrates farther in leaf litter, and its decline follows the Beer-Lambert law (Facelli \& Pickett, 1991):

$$
\mathrm{RI}=100 \mathrm{e}^{\mathrm{bM}}
$$

where RI is relative illuminance, $b$ is transmittance constant of litter, and $\mathrm{M}$ is the amount of litter per $\mathrm{g} / \mathrm{m}^{2}$. Light loss in litter is strong, but since the Beer-Lambert law is exponential, small amounts of light penetrate deep into the litter. Often, species in these habitats have enlarged eye size in order to retain the ability to form images (Warrant, 2006; Tierney et al., 2017). On the other hand, there are eyeless troglomorphic species known from twilight habitats (Prendini et al., 2009; Heads, 2010). There are additional troglomorphic taxa from deep litter and deep soil, but rare in caves, such as Symphyla.

A cave in the Yucatan Peninsula of Mexico-Sistema Muévelo Rico-allowed us to examine and challenge the critical role of light in distinguishing between subterranean and surface habitats. As we describe in detail below, this cave, more than $1 \mathrm{~km}$ in length, has at least 12 openings to the surface, and very little dark zone. In fact, by some classifications, it is not even a cave because of the near absence of a dark zone. By a strict definition of caves as zones of darkness, we would not expect to find species limited to caves (troglobionts) with reduced eyes and pigments (troglomorphic species). On the other hand, Sistema Muévelo Rico is an environment with greatly attenuated variation in temperature and relative humidity, and an environment where all or nearly all organic matter and nutrients come from the surface, also features typical of caves (Culver \& Pipan, 2009). In a contrasting view of the cave habitat, some authors (Moseley, 2009), dating back to Racovitza (1907) argue that the real subterranean habitats, the one that harbors source populations of troglomorphic species, are the cracks and crevices found in any cave. Moseley (2009) proposes that all caves are ecotones. By this viewpoint, there should be no reduction in troglomorphic species in Sistema Muévelo Rico, and their presence in cave passages is a by-product of movement from the source population in the cracks and crevices.

Overall, our goals were to:

- Characterize the aspects of the atmosphere (temperature, relative humidity, and light) and lithosphere (soil organic matter) in this photic subterranean habitat.

- Characterize the biosphere, especially with respect to troglomorphic species and visually oriented predators.

- Re-examine the absence of light as the defining feature of subterranean environments.

- Explore the tradeoffs that troglomorphic species face between the negative features of light and the positive features of organic matter and relative humidity.

\section{MATERIALS AND METHODS}

\section{Sistema Muévelo Rico}

Sistema Muévelo Rico (20³2'05.1"N, 87²1'16.5"W) is located near the settlement of Paamul, in the Mexican state of Quintana Roo (Fig. 1). Its surveyed length is $1,151 \mathrm{~m}$ with a depth of $4 \mathrm{~m}$ (QRSS, 2017). The cave, with an elevation of $7 \mathrm{~m}$, is less than $2 \mathrm{~km}$ from the Caribbean Sea. Quintana Roo is characterized by intense cave development, with $1,367.5 \mathrm{~km}$ of surveyed underwater passages and $277.2 \mathrm{~km}$ surveyed dry passage (QRSS, 2017). Land around the cave is a dense second growth subtropical forest.

Cave development in coastal regions like Quintana Roo involves dissolution of limestone at the saltwaterfreshwater interface in laminar flow regimes (Mylroie \& Mylroie, 2007; Mylroie, 2013), but also with modification by dissolution in freshwater turbulent flow regimes. Kambesis and Coke (2013) describe the passage geometry of caves like Sistema Muévelo Rico as linear phreatic. Due to uplift of the Yucatan platform, caves become dry and rapidly erode in the eogenetic limestone (Spaw, 1978; Kambesis \& Coke, 2013). As a consequence, Sistema Muévelo Rico has a large number of entrances, more than 12, if skylights are included. Because of the close proximity of the water table to the surface, vertical development and subterranean terrestrial habitats are very restricted. 


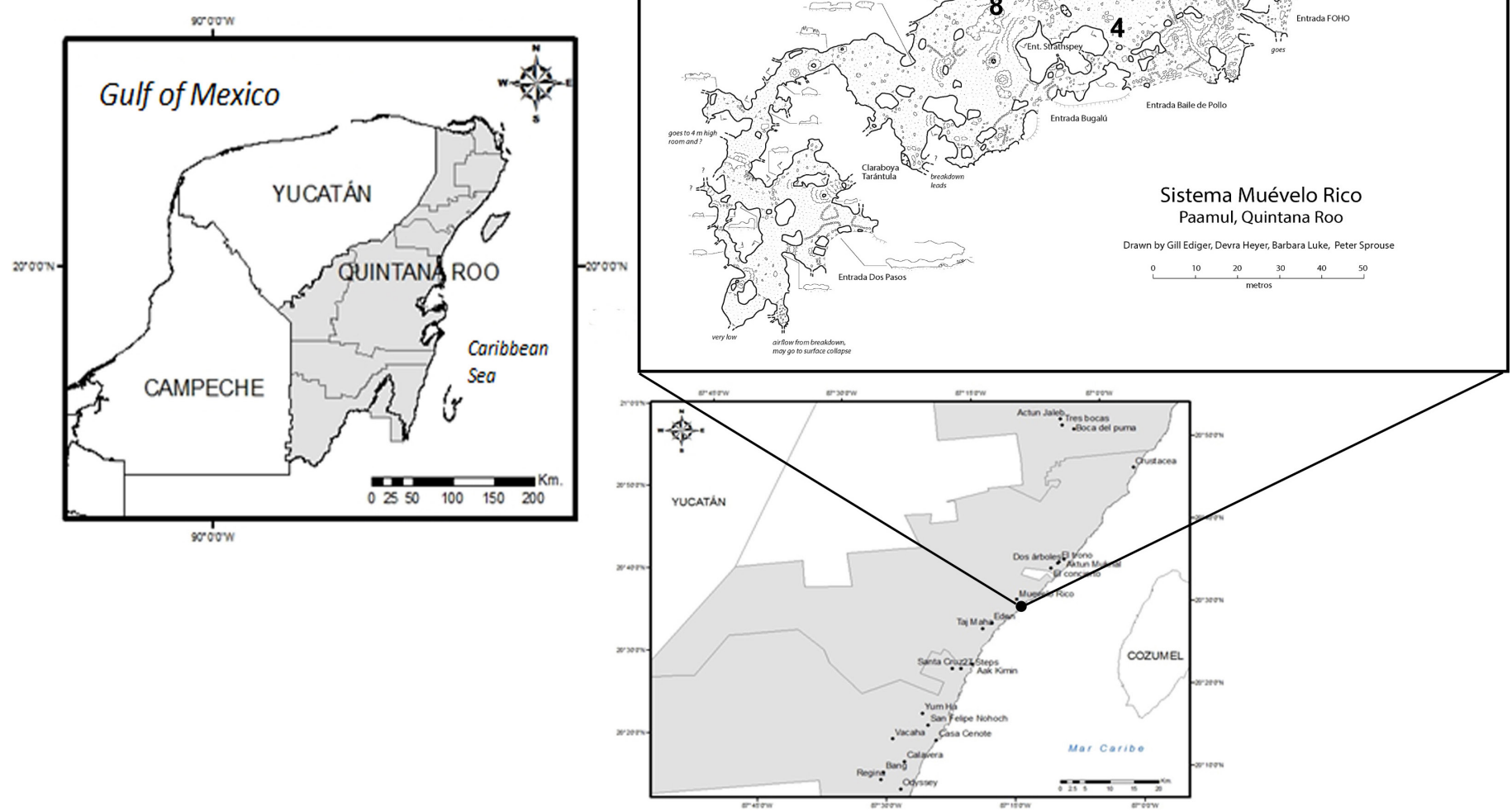

Fig. 1. Locator map and map of Sistema Muévelo Rico. Numbers indicate location of monitoring stations. Map drafted by P. Sprouse, 2014.

\section{Environmental sampling}

We established eight environmental monitoring sites in the cave (Fig. 1). At all eight stations, we installed $\mathrm{Hobo}^{\mathrm{TM}}$ temperature and relative humidity dataloggers for a period from 5 April 2015 to 28 March 2016, resulting in a total of 8593 observations at each site. One of the stations was at the main entrance to the cave. At stations 1 through 4 , Hobo $^{\mathrm{TM}}$ Pendant temperature/light dataloggers sensors were installed. Unfortunately, light levels were all below the detection limit of the device, which in any case measures relative light intensity.

Light was measured in March 2017 using a Konica Minolta $^{\mathrm{TM}} \mathrm{T}-10 \mathrm{~A} / \mathrm{T}$ illuminance meter with a detection limit of 0.01 lux. Measurements were taken at midday (11:00AM to 1:00PM). We established a number of transects in the cave running from entrances (including skylights) at $5 \mathrm{~m}$ intervals up to a distance of $30 \mathrm{~m}$. In most cases, measurements were also taken at $1 \mathrm{~m}$ intervals for the first five $\mathrm{m}$ from the entrance. In addition, we measured light at each of the eight sampling stations, as well as at additional points within the cave. All in all, we had 75 measurements of light. We also did repeated samples at one minute intervals at a skylight and $2 \mathrm{~m}$ from the skylight to assess variability over short time periods.

In order to determine whether any light was present, photographs in the direction of an entrance were taken using a Nikon ${ }^{\mathrm{TM}}$ D5100 digital camera at a light sensitivity of ISO 6400. Photographs were taken at all eight stations, using an automatic exposure.

Percent organic matter was estimated from cave soil samples taken from the top $1 \mathrm{~cm}$ at all eight stations, one from the small completely dark zone, and one from five additional entrances. No surface samples were taken. Samples were dried at $70^{\circ} \mathrm{C}$ for 48 hours. An aliquot was weighed and placed in a muffle furnace at $500^{\circ} \mathrm{C}$ for one hour, and weight loss was used to measure the weight of organic matter.

\section{Fauna sampling}

At three month intervals during the environmental monitoring year, careful visual censuses (a minimum of 20 person-minutes) of all the organisms with a $2 \mathrm{~m}$ radius of the monitoring devices were done. Representative samples of each species were collected and preserved in 70\% alcohol. Because most of the species are undescribed, we categorized them according to broad taxonomic group. Focus was on two ecological categories-pigmented and eyed predators, and species showing obvious troglomorphic characteristics of reduced eyes and pigment, and elongated appendages. Additional one time only biological collections were made in the completely dark zone, and at two entrances in March of 2017. 


\section{Data analysis}

Temperature and relative humidity data were plotted in Excel $^{\mathrm{TM}}$. Statistical analysis was done in $\mathrm{JMP}^{\mathrm{TM}}$, including spectral analysis to determine if any 24 hour cyclicity occurs. A map of light intensity was created from the illuminance meter data, as well as direct observation, using the following categories:

- No light detectable either by the illuminance meter, Nikon ${ }^{\mathrm{TM}}$ D5100 photographs, or by the human eye

- Trace light-not detectable by illuminance meter (>0.01 lux) but detectable by Nikon ${ }^{\mathrm{TM}}$ D5100 photographs and by the human eye.

- Dim light-0.01 to 1 lux

- Moderate light-1 to 100 lux

- Daylight- >100 lux

\section{RESULTS}

\section{Temperature and relative humidity}

Variation in temperature and relative humidity is summarized in Table 1 and Fig. 2. At all seven stations, temperature was more variable than relative humidity, according to the coefficients of variation. Unfortunately, the datalogger at station 8 failed, and no data were available. At all measured stations, there was a noticeable drop in winter temperatures, and overall, stations 4 and 5 were the most variable, with ranges of more than $12^{\circ} \mathrm{C}$ (Table 1$)$. Station 5 is located right at the main entrance to the cave (Fig. 1). All stations had a temperature range of at least $6^{\circ} \mathrm{C}$.

Relative humidity $(\mathrm{RH})$ presented a more complex pattern with different patterns at different stations (Table 1, Fig. 2). Stations 1, 3, and 6, were very stable throughout the year, with $\mathrm{RH}$ always above $92 \%$. Station 2 showed consistent lower RH in winter and spring, with minimums below 90\%. Station 7 had a $\mathrm{RH}$ minimum similar to that of Station 2, but $\mathrm{RH}$ was $100 \%$ most of the year, except for a brief period in the spring. Stations 4 and 5 showed consistent lower $\mathrm{RH}$ in spring and variable $\mathrm{RH}$ in the winter, with minimums below $80 \%$.

Spectral analysis of variation in temperature showed a peak cycle at 24 hours, although the strength (spectral density) varied considerably among stations (Fig. 3). Stations 4 and 5 showed a strong daily cycle (spectral density greater than 30), stations 1 and 2 a moderate cycle, and stations 3,6 , and 7 showed a weak cycle (spectral density less than 5).

Spectral analysis of variation in relative humidity showed a somewhat different pattern (Fig. 4). Stations
4 and 5 had strong daily cycles (spectral densities greater than 100), and only station 2 had a moderate cycle. Stations 1, 3, 6, and 7 had very weak cycles, with spectral densities less than 2 . Of course, it is not known if organisms can detect these weak cycles.

\section{Light}

Because light incident on the surface varies, we estimated the extent of mid-day variation at the skylight near the entrance Baile de Pollo. The mean lux directly beneath the skylight was 110.7 , with a coefficient of variation of $49.6 \%$ for measurements taken at one minute intervals for ten minutes. At a distance of $2 \mathrm{~m}$, mean lux was 0.24 with a coefficient of variation of $40.2 \%$. Because of this variation, we lumped values into large categories. These data also illustrate how rapidly light falls off from vertical skylights. Even for horizontal entrances such as Cumbria, the fall-off of light is rapid. After $15 \mathrm{~m}$, lux were reduced from 576 to 22 (Fig. 5).

Photographs were taken with a Nikon D5100 digital camera using the high sensitivity of the camera to detect the light. In each of the established sampling sites light could be detected as shown in Fig. 6. And only in the area that was previously designated as completely dark with the light meter and the human eye was the image completely dark (not shown).

Figure 7 shows light zonation in the cave. Incident light in the large gray area in Fig. 7 was not detectable with our light meter. However, throughout this area, we could detect light, from one or more entrances or skylights. This light is less than 0.01 lux but greater than zero, as is possible to see in the images of Fig. 6. There is a small true dark zone, at least sense that neither the meter nor the human eye could detect light.

\section{Organic matter}

Percent organic matter in the twilight zone averaged twice that of the dark zone, but the dark zone was based on a single measurement (Table 2). Entrance values in turn averaged more than three times that of the twilight zone stations. The exceptionally high value at the skylight near the Baile de Pollo entrance was likely due to the presence of guano. Sources of organic matter in the cave are bat guano, guano from other cave visitors, aerial movement of detritus and other particulate organic matter, and tree roots penetrating into the cave. Flooding is high unlikely because of the highly porous nature of the limestone.

Table 1. Means, standard deviations, coefficients of variation, medians, minima, and maxima for temperature and relative humidty for stations 1 through 7 (see Fig. 1). No data are available for station 8 because of logger failure. Based on 8,593 hourly readings.

\begin{tabular}{|c|c|c|c|c|c|c|}
\cline { 2 - 7 } \multicolumn{1}{c|}{} & \multicolumn{7}{c|}{ Relative Humidity } \\
\hline Station & Mean & SD & CV & Median & Minimum & Maximum \\
\hline $\mathbf{1}$ & 99.71 & 0.65 & 0.65 & 100.00 & 95.16 & 100.00 \\
\hline $\mathbf{2}$ & 98.24 & 2.42 & 2.46 & 99.50 & 87.95 & 100.00 \\
\hline $\mathbf{3}$ & 99.95 & 0.37 & 0.37 & 100.00 & 92.13 & 100.00 \\
\hline $\mathbf{4}$ & 98.19 & 3.00 & 3.06 & 100.00 & 77.13 & 100.00 \\
\hline $\mathbf{5}$ & 97.06 & 4.40 & 4.53 & 99.63 & 69.12 & 100.00 \\
\hline $\mathbf{6}$ & 99.98 & 0.19 & 0.19 & 100.00 & 95.39 & 100.00 \\
\hline $\mathbf{7}$ & 99.96 & 0.41 & 0.41 & 100.00 & 89.31 & 100.00 \\
\hline
\end{tabular}

\begin{tabular}{|c|c|c|c|c|c|}
\hline \multicolumn{7}{|c|}{ Temperature } \\
\hline Mean & SD & CV & Median & Minimum & Maximum \\
\hline 24.56 & 1.24 & 5.05 & 25.02 & 18.72 & 29.96 \\
\hline 24.92 & 1.44 & 5.78 & 25.38 & 20.34 & 27.16 \\
\hline 24.46 & 1.60 & 6.54 & 25.11 & 17.53 & 26.13 \\
\hline 24.63 & 2.09 & 8.49 & 25.31 & 15.15 & 28.12 \\
\hline 24.53 & 2.41 & 9.82 & 25.06 & 12.78 & 29.39 \\
\hline 24.49 & 1.26 & 5.14 & 24.97 & 19.25 & 25.87 \\
\hline 24.53 & 1.38 & 5.63 & 25.06 & 18.70 & 25.99 \\
\hline
\end{tabular}



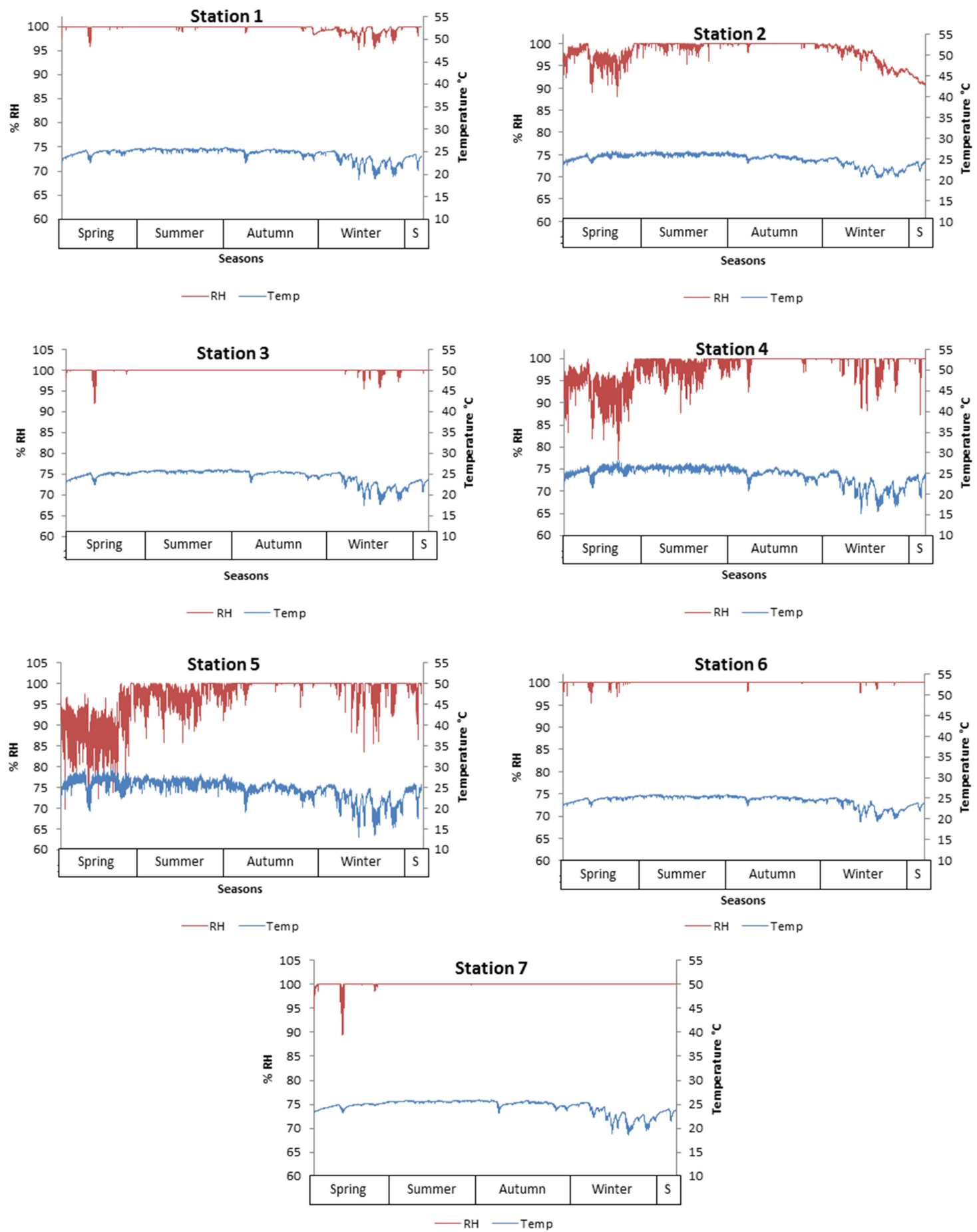

Fig. 2. Plot of temperature and relative humidity values for the seven monitoring stations (see Fig. 1 for station locations).

\section{Fauna}

A total of six groups of troglomorphic taxa were found, based on their reduced eyes and pigment:

- Araneae

- Collembola

- Hemiptera

- Isopoda

- Opiliones

- Scorpiones

Reddell (1981) listed four species of troglobiotic spiders (Theotime martha, Oonopscoccus sp., Metagonia torete, and Pholcophora pearsei), and Palacios-Vargas et al. (2014-2015) one troglobitic spider (Wanops coecus) from caves in Quintana Roo, but we were unable to identify the spiders we collected. PalaciosVargas et al. (2014-2015) also listed one troglobitic Collembola from Quintana Roo (Metasinella falcifera).
A total of seven groups of eyed predators were found:

- Amblypygii

- Araneae

- Geophilomorpha

- Mantodea

- Opiliones

- Pseudoscorpiones

- Scorpiones

Reddell (1981) states that Paraphrynus raptator (Amblypygii) is a widespread and common troglophile in caves in Quintana Roo, and perhaps was the species we saw.

The distribution of these taxa with respect to the eight monitoring stations is shown in Fig. 8. There is little or no difference in the distribution of the eyed predators and the troglomorphic taxa, their potential prey. 


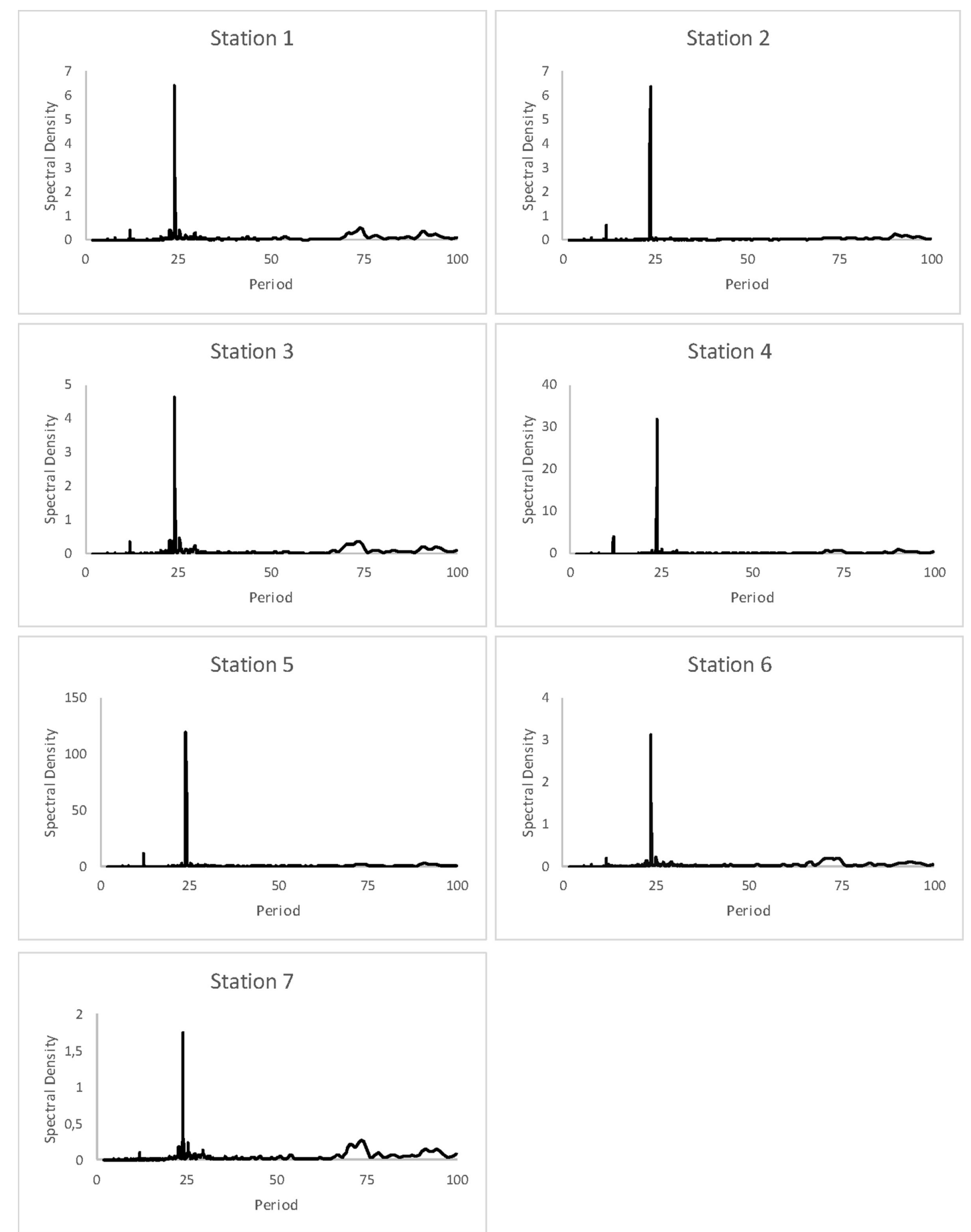

Fig. 3. Spectral analysis of cycles in temperature at the seven monitoring stations. Spectral density indicates the strength of the signal. Spikes are at 24 hours.

A similar diagram of distribution for troglomorphic and eyed predatory taxa, based on light intensity, is shown in Fig. 9, where additional information on occurrence was included for two entrances and the dark zone, sampled in March of 2017. The dark zone is of particular interest because only one troglomorphic taxon (Araneae) was observed.

The pool near Entrada Cumbia (Fig. 1) is connected to groundwater, and in a zone of illuminance of between 100 and 500 lux. Four species of stygobionts, all with reduced or absent eyes and pigment were found within $1 \mathrm{~m}$ of the surface of the pool: Antromysis cenotensis (Mysidacea), Creaseriella anops (Isopoda), Typhlatya mitchelli (Caridea), Creaseria morleyi (Caridea), and T. pearsei (Caridea). No other macroinvertebrates or vertebrates were observed.

\section{DISCUSSION}

\section{The environment in Sistema Muévelo Rico}

The environment of Sistema Muévelo Rico shares characteristics of both epigean and subterranean habitats. It shares with epigean habitats the presence of light and diurnal cycles of temperature and relative humidity, but these features are greatly diminished relative to epigean habitats. On the other hand, the very high relative humidity, often at saturation, is typical of subterranean habitats.

We have no local data from either caves or surface habitats to compare values of organic matter, but the values listed in Table 2 are high (mean $=8.54 \%$ for the sampling stations), compared to values from temperate zone caves, e.g., Mammoth Cave 


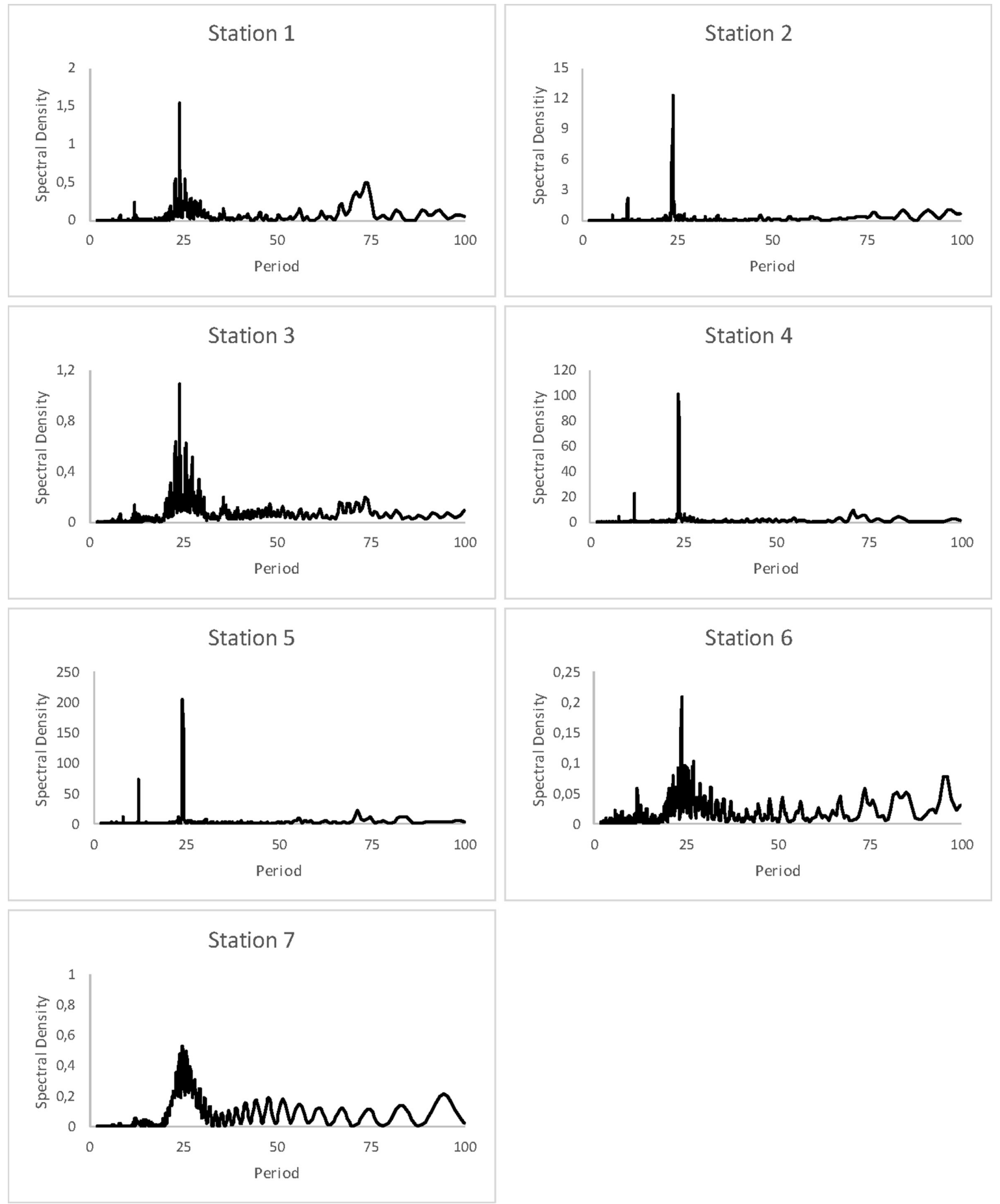

Fig 4. Spectral analysis of cycles in relative humidity at the seven monitoring stations. Spectral density indicates the strength of the signal. Spikes are at 24 hours.

in Kentucky (Poulson \& Culver, 1969), which averaged $3.02 \%$ (S.E. $=0.24, \mathrm{n}=22)$. Within Sistema Muévelo Rico, the dimly illuminated part of the cave is richer in organic matter than the dark zone, and it would seem very likely that cracks and crevices have even less organic matter because transport to the cracks and crevices must be much less than transport to the small aphotic zone of the cave.

Very little of Sistema Muévelo Rico is aphotic, and an apt description of the environment is a "photic subterranean environment". While the cave is certainly unusual, the light environment of the cave is hardly unique. A number of nearby caves, such as Sistema Pata de Jaguar, have extensive zones very similar to Sistema Muévelo Rico, but connected to an even larger aphotic zone. Additionally, every cave has an entrance zone where light diminishes with distance into the cave. Because the decline of light in shallow habitats like leaf litter and soil is exponential, according to the Beer-Lambert law (Facelli \& Pickett, 1991), light may extend farther into the ground in these shallow subterranean habitats than previously believed. What makes Sistema Muévelo Rico special is that light occupies nearly all of the cave, which is itself quite long $(>1 \mathrm{~km})$, and that troglomorphic species are found throughout the cave.

We do not know the values of illuminance below 0.01 lux, but roughly half the cave has illuminance values below this. In these parts of the cave, light appears as points, which are the entrances and skylights. By way of comparison, the illuminance of 


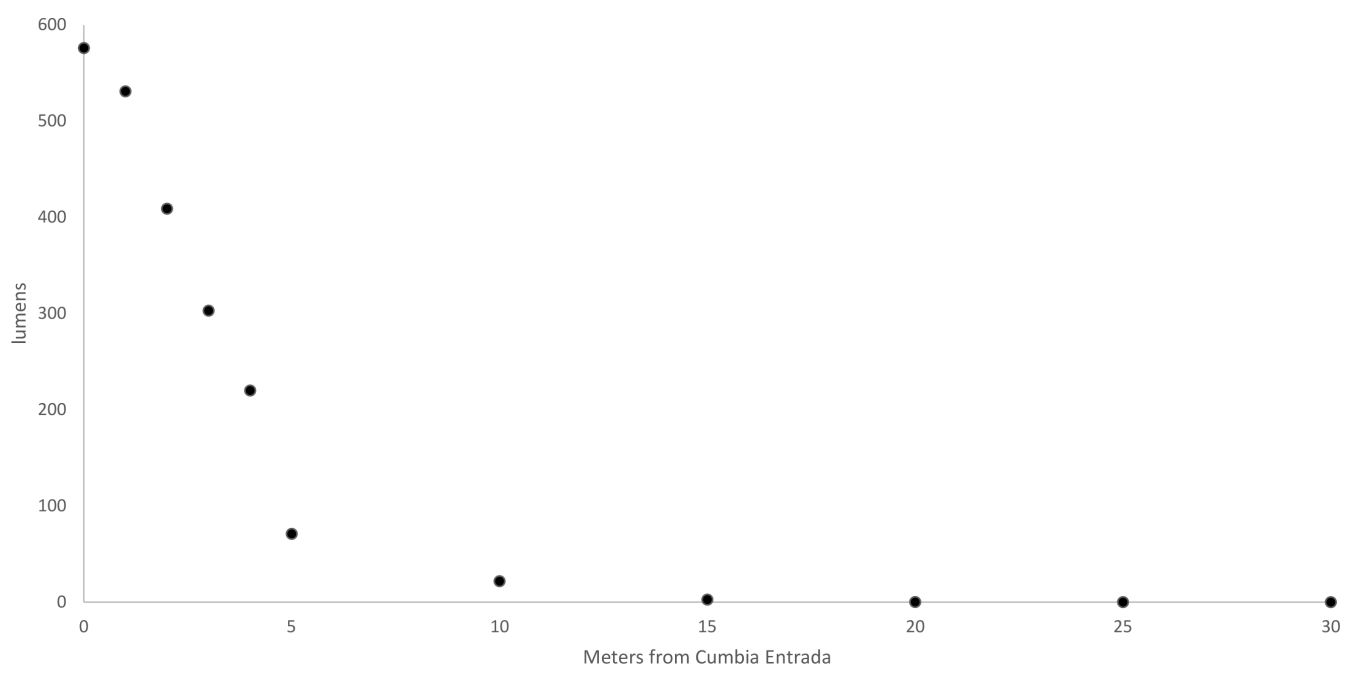

Fig. 5. Light incidence at a horizontal entrance. By $30 \mathrm{~m}$, incident light was less than 0.01 lumens, below the sensitivity of the light meter.
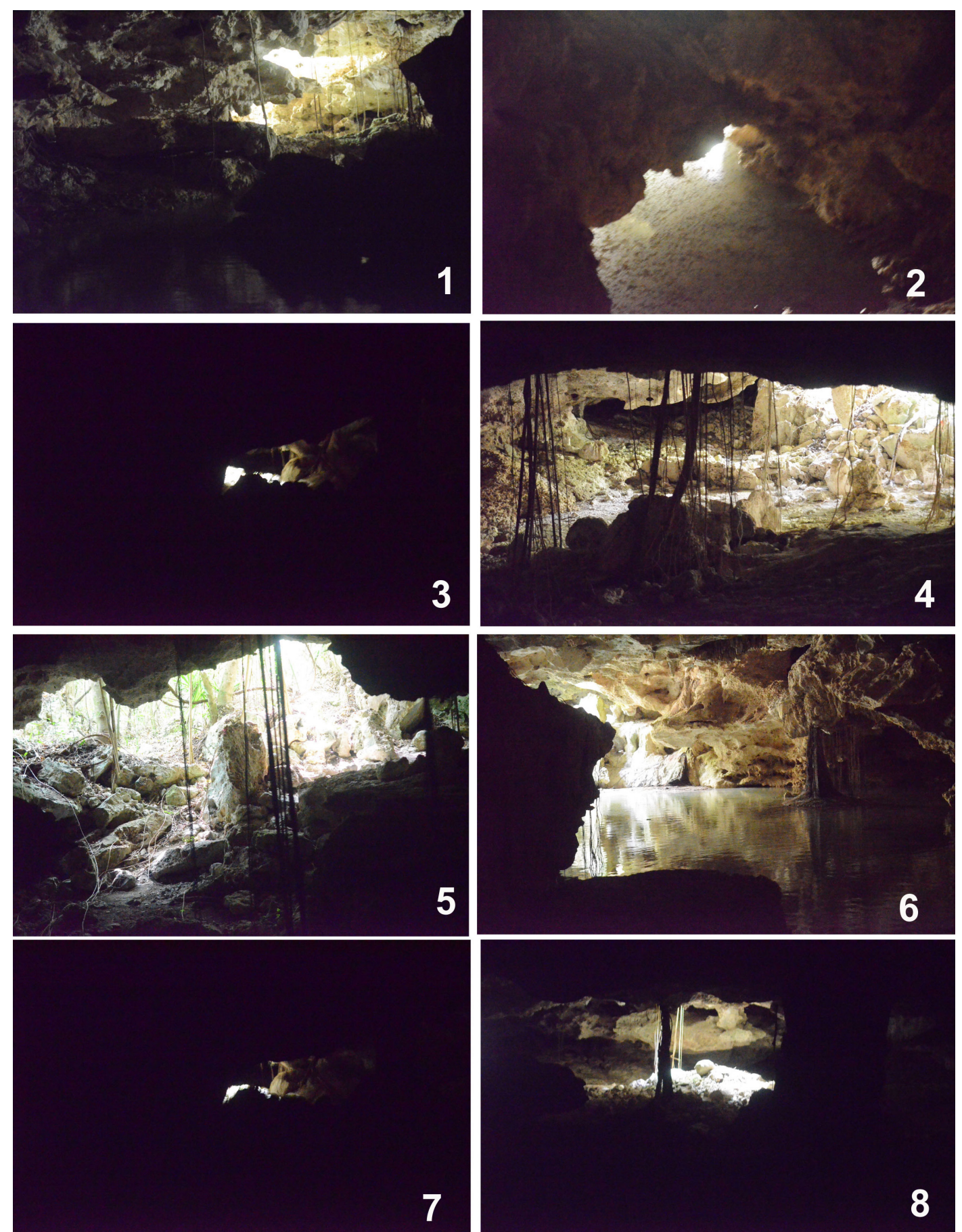

Fig. 6. Photographs at ISO 6400 using a Nikon D5100. The numbers correspond to each sampling station. 
a quarter moon night sky is 0.01 lux, and a clear moonless night is 0.001 lux (Johnsen, 2012).

\section{The environment of Sistema Muévelo Rico with respect to natural selection}

We have shown that eye reduced species occur in Sistema Muévelo Rico, and this suggests that either the ability to form images in these low light environments is so reduced as to make only the detection of light important (especially for circadian clocks, see Friedrich (2013), or that the primary habitats of troglomorphic species are the cracks and crevices of the limestone, which are more extensive in these eogenetic limestones than in older, more compressed limestones. That cracks and crevices are the primary habitat of obligate subterranean dwelling species is the view of Racovitza (1907), Karaman (1954), and Moseley (2009). The issue is not really whether the species utilize cracks and crevices. The answer is certainly that they do. The issue is why relatively large numbers are found in the cave passage. It seems unlikely that the individuals in the cave itself have just blundered into the cave, but rather that there is something in the larger passages that brings out troglomorphic species from the relative safety of cracks and crevices to face and increased number of predators. The most likely reason for their presence in the cave itself is that there is more organic matter in the large passages than in the cracks and crevices. It would seem that just as there is no fauna limited only to caves, as Karaman (1954) suggests, there is no fauna limited only to cracks and crevices.

It is possible that the number of troglomorphic species we observed is reduced relative to aphotic caves. It is difficult to answer this question definitively because of the lack of studies of the terrestrial cave fauna of the region. Palacios-Vargas et al. (2014-2015) list a large number of facultative cave dwellers from Quintana Roo, several times more than the number of troglobionts. This suggests that the troglomorphic fauna of Quintana Roo is not particularly diverse. This is in contrast to the relatively rich troglomorphic aquatic fauna (Mejia-Ortíz et al. 2013).

The other issue is why there do not appear to be any species adapted to low light, with larger eyes, but there are others ways to increase light sensitivity beyond increased eye size. Perhaps illuminance is too low for image formation so that larger eyes have

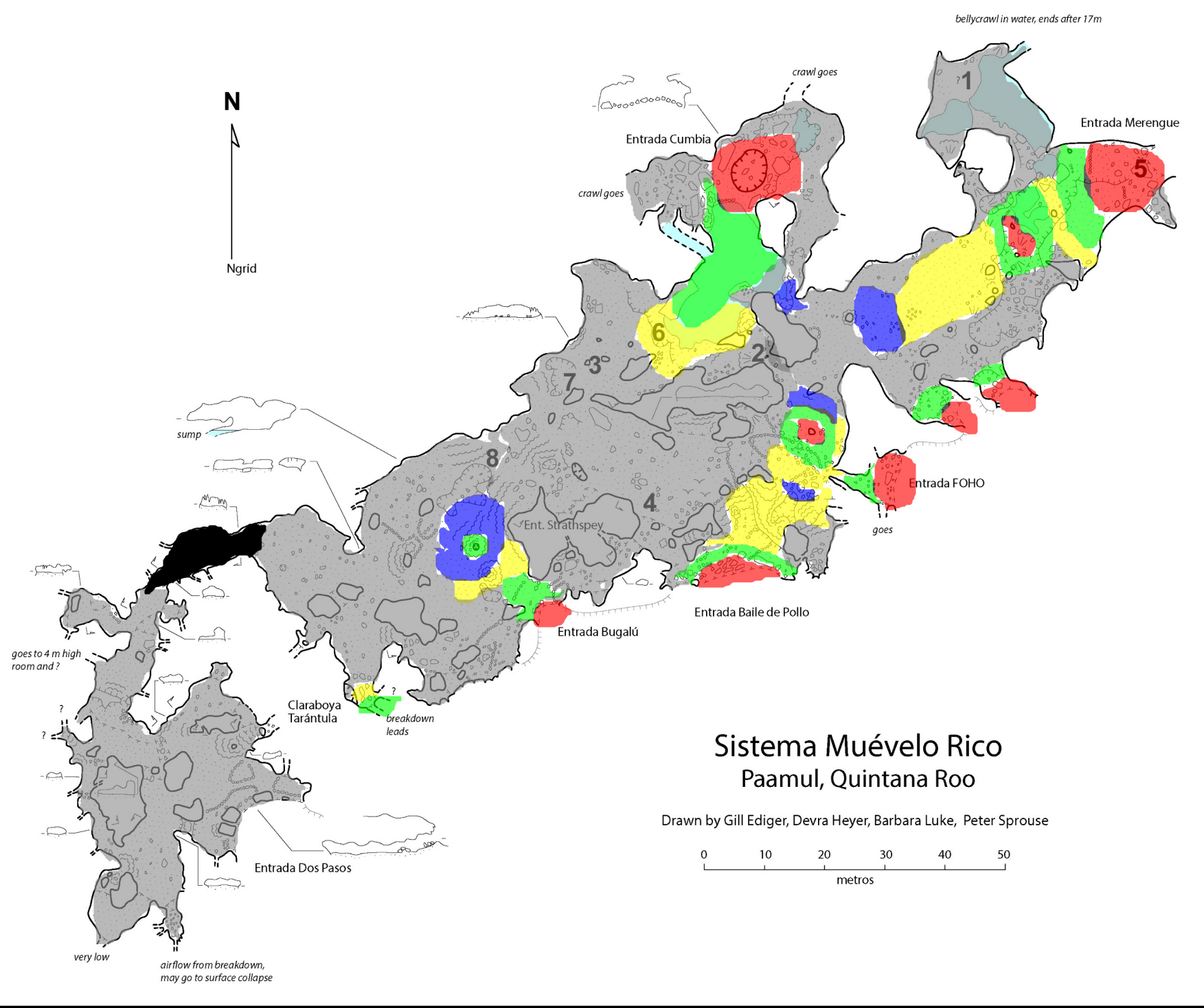

Fig. 7. Map of zones of incident light in Sistema Muévelo Rico. Red color is day light; Green color is indirect daylight (>100 lux); Yellow color is moderate light; Blue color is dim light; grey color is trace light; and black color is the true dark zone. 
Table 2. Percent organic matter at the eight monitoring stations, four additional entrances and skylights, and one sample from the aphotic zone. Station 5 is listed with the entrances because it was located at the main entrance to the cave.

\begin{tabular}{|c|c|c|c|c|}
\hline Sites & Dry weight (g) & Ashed weight (g) & $\begin{array}{c}\text { Organic matter } \\
\text { weight }(\mathrm{g})\end{array}$ & $\begin{array}{c}\text { Percent organic } \\
\text { matter }\end{array}$ \\
\hline \multicolumn{5}{|l|}{ Interior Stations } \\
\hline Station 1 & 33.328 & 31.137 & 2.190 & 6.572 \\
\hline Station 2 & 33.197 & 29.932 & 3.265 & 9.836 \\
\hline Station 3 & 42.420 & 40.245 & 2.175 & 5.128 \\
\hline Station 4 & 40.206 & 34.009 & 6.197 & 15.413 \\
\hline Station 6 & 31.567 & 35.997 & 4.430 & 14.034 \\
\hline Station 7 & 42.041 & 39.479 & 2.562 & 6.094 \\
\hline Station 8 & 18.596 & 18.089 & 0.508 & 2.730 \\
\hline Mean \pm S.E. & & & & $8.544 \pm 1.789$ \\
\hline \multicolumn{5}{|l|}{ Aphotic Zone } \\
\hline Dark zone & 39.172 & 37.236 & 1.936 & 4.942 \\
\hline \multicolumn{5}{|l|}{ Entrances and Skylights } \\
\hline Claraboya Entrance 1 & 34.672 & 28.818 & 5.853 & 16.882 \\
\hline Entrance bungalow & 37.646 & 34.891 & 2.755 & 7.319 \\
\hline Skylight close station 8 & 34.185 & 27.217 & 6.968 & 20.383 \\
\hline Baile de Pollo Entrance & 41.063 & 36.980 & 4.082 & 9.942 \\
\hline Skylight close entrance baile de pollo & 10.760 & 3.875 & 6.885 & 63.990 \\
\hline Station 5 & 38.281 & 34.076 & 4.205 & 10.985 \\
\hline Mean \pm S.E. & & & & $21.583 \pm 8.705$ \\
\hline
\end{tabular}

no advantage. There is evidence of use of the cave by nocturnal mammals. Game cameras in the Jaguar complex of caves have documented jaguar (Panthera orca), puma (Puma concolor), margay (Leopardus wiedii), possum (Didelphimorphia), fox (Vulpes vulpes), and paca (Cuniculus) (Sprouse, unpublished data).

The presence of dim light may explain the widespread ability of apparently cave-limited species to detect light and to have a biological clock (Friedrich, 2013). Perhaps these species also encounter photic subterranean environments. Photic habitats, even dimly lit ones, are both a source of food and a source of danger from visually oriented predators for any species primarily living in aphotic habitats. At low illuminance, that danger from visually oriented predators may be quite low.

For stygobionts in the cave, almost certainly the primary habitat for these species is the deeper, dark zone, and is likely that their presence near the surface in a relatively well-lit pool is the result of active foraging in an area of higher levels of organic matter. The cost of this activity is the risk of predation, but we saw no predators in the pool.

\section{Future research and unanswered questions}

Almost all aspects of this study could be fruitfully explored in more detail. First, while technically difficult (see Johnsen, 2013), the measurement of illuminance below 0.01 lux would be informative. The measurement of light in Sistema Muévelo Rico is actually easier than in many photic subterranean habitats like leaf litter because the habitat itself in the cave need not be disrupted in order to measure light. Second, the scenario that we have put forward here, that this dimly lit habitat is a habitat with both risks (predation) and rewards (more food) needs verification, both by careful observation of the inhabitants of Sistema Muévelo Rico and by expansion to other

\begin{tabular}{|c|c|c|c|c|c|c|c|c|}
\hline & 1 & 2 & 3 & 4 & 5 & 6 & 7 & 8 \\
\hline \multicolumn{9}{|l|}{ Araneae } \\
\hline \multicolumn{9}{|l|}{ Ambypygii } \\
\hline \multicolumn{9}{|l|}{ Collembola } \\
\hline \multicolumn{9}{|l|}{ Opiliones } \\
\hline \multicolumn{9}{|l|}{ Araneae } \\
\hline \multicolumn{9}{|l|}{ Opiliones } \\
\hline \multicolumn{9}{|c|}{ Pseudoscorpiones } \\
\hline \multicolumn{9}{|c|}{ Geophilomorpha } \\
\hline \multicolumn{9}{|l|}{ Scorpiones } \\
\hline \multicolumn{9}{|l|}{ Isopoda } \\
\hline \multicolumn{9}{|l|}{ Hemiptera } \\
\hline \multicolumn{9}{|l|}{ Mantodea } \\
\hline Scorpiones & & & & & & & & \\
\hline
\end{tabular}

Fig. 8. Occurrence, by station, of troglomorphic taxa (in black) and eyed predatory taxa (in gray). 


\begin{tabular}{|l|l|c|c|c|c|}
\cline { 2 - 6 } \multicolumn{1}{c|}{} & $\begin{array}{c}\text { Complete } \\
\text { darkness }\end{array}$ & $\begin{array}{c}\text { Trace } \\
\text { (<0.01 lumens) }\end{array}$ & $\begin{array}{c}\text { Dim light } \\
\text { (0.01 to 1 lumens) }\end{array}$ & $\begin{array}{c}\text { Moderate light } \\
\text { (1 to 100 lumens) }\end{array}$ & $\begin{array}{c}\text { Daylight } \\
\text { (>100 lumens) }\end{array}$ \\
\hline Araneae & & & & \\
\hline Ambypygii & & & & \\
\hline Collembola & & & & \\
\hline Opiliones & & & & \\
\hline Araneae & & & & \\
\hline Opiliones & & & & \\
\hline Pseudoscorpiones & & & & \\
\hline Geophilomorpha & & & & \\
\hline Scorpiones & & & & \\
\hline Isopoda & & & & \\
\hline Hemiptera & & & & & \\
\hline Mantodea & & & & \\
\hline Scorpiones & & & & \\
\hline
\end{tabular}

Fig. 9. Occurrence, by light zone, of troglomorphic taxa (in black) and eyed predatory taxa (in gray).

caves, ones with larger dark zones. This would allow examination of the question of how many of the regional species pool of troglobionts are found in the dimly lit areas. Third, greater taxonomic precision would be useful.

Most importantly, the fauna and environment of Sistema Muévelo Rico should be cause of reexamination of the boundary between light and dark, and the interactions occurring at this boundary.

\section{CONCLUSIONS}

Sistema Muévelo Rico is an environment that is intermediate between photic and aphotic environments. The cave is aphotic in only a small section, but in most of the cave, illuminance is less than 0.01 lux. In other respects, the environment is intermediate-a reduced cyclicity and variability of temperature and relative humidity occurs. Organic matter is also intermediate, with an average of $8.5 \%$ in the cave. The invertebrate fauna of the cave includes both aphotic subterranean and photic surface fauna. Both components occur throughout the cave. The subterranean fauna likely occurs primarily in cracks and crevices, but forages for food in the cave itself.

\section{ACKNOWLEDGEMENTS}

The authors thank Benjamin Hutchins for first alerting us to the potential interest of this cave. Benjamin Schwartz, Christian Martinez, Ximena Rosales, Jesus Cupul, Alex Contreras, Vanessa Tafoya, and Rodrigo Cisneros assisted with field work. William K. Jones provided advice about measuring light photographically. Alberto Rivero gave permission to visit the cave. Comments from the reviewers and the editor greatly improved the manuscript.

\section{REFERENCES}

Bilandžija H., Ma L., Parkhurst A. \& Jeffery W.R., 2013 - A potential benefit of albinism in Astyanax cavefish: downregulation of the oca2 gene increases tyrosine and catecholamine levels as an alternative to melanin synthesis. PLoS One, 8: e80823.

https://doi.org/10.1371/journal.pone.0080823
Christiansen K.A., 1962 - Proposition pour la classification des animaux cavernicoles. Spelunca, 2: 75-78.

Ciani A., Goss K.U. \& Schwarzenbach R.P., 2005 - Light penetration in soil and particulate minerals. European Journal of Soil Science, 56: 561-574.

https://doi.org/10.1111/j.1365-2389.2005.00688.x

Culver D.C. \& Pipan T., 2009 - Biology of caves and other subterranean habitats. Oxford University Press, Oxford, 254 p.

Culver D.C. \& Pipan T., 2014 - Shallow subterranean habitats. Ecology, evolution and conservation. Oxford University Press, Oxford, 258 p. https://doi.org/10.1093/acprof:oso/9780199646173. $\underline{001.0001}$

Eigenmann C.H., 1909 - Cave vertebrates of America. A study in degenerative evolution. Carnegie Institution of Washington, Washington, $232 \mathrm{p}$.

Facelli J.M. \& Pickett S.T.A., 1991 - Plant litter light penetration and effects on an old-field plant community. Ecology, 72: 1025-1031.

https://doi.org/10.2307/1940602

Fenolio D., 2016 - Life in the dark. Iluminating biodiversity in the shadowy haunts of planet Earth. Johns Hopkins University Press, Baltimore, 317 p.

Fišer C., Pipan T. \& Culver D.C., 2014 - The vertical extent of groundwater metazoans: an ecological and evolutionary perspective. Bioscience, 64: 971-979. https://doi.org/10.1093/biosci/biu 148

Friedrich M., 2013 - Biological clocks and visual systems in cave-adapted animals at the dawn of speleogenomics. Integrative and Comparative Biology, 53: 50-67. https://doi.org/10.1093/icb/ict058

Graham R.E., 1962 - The Pacific tree frog, Hyla regilla, a trogloxene from California caves. Cave Notes, 4: 17-22.

Graham R.E., 1968 - The twilight moth, Triphosa haesitata (Lepidoptera: Geometridae), from California and Nevada caves. Caves and Karst, 10: 41-48.

Heads S.W., 2010 - The first fossil spider cricket (Orthoptera: Gryllidae: Phalangopsinae): 20 million years of troglobiomorphosis or exaptation in the dark? Zoological Journal of the Linnean Society, 158: 56-65. https://doi.org/10.1111/j.1096-3642.2009.00587.x

Howarth F.G., 1980 - The zoogeography of specialized cave animals: a bioclimatic model. Evolution, 34: 394-406. https://doi.org/10.1111/j.1558-5646.1980.tb04827.x Hüppop K., 2000 - How do cave animals cope with the food scarcity in caves? In: Wilkens H., Culver D.C. \& Humphreys W.F. (Eds.), Subterranean ecosystems. Elsevier, Amsterdam, p. 159-188. 
Johnsen S., 2012 - The optics of life. A biologist's guide to light in nature. Princeton University Press, Princeton, $336 \mathrm{p}$.

Johnsen S., Kelber A., Warrant E.J., Sweeney A., Lee R.H. Jr. \& Hernández-Andrés J., 2006 - Crepuscular and nocturnal illumination and its effects on color perception by the nocturnal hawkmoth Deilophila elpinor. Journal of Experimental Biology, 209: 789-800.

https://doi.org/10.1242/jeb.02053

Kambesis P.N. \& Coke J.G., 2013 - Overview of the controls on eogenetic cave and karst development in Quintana Roo, Mexico. In: Lace M.J. \& Mylroie J.E. (Eds.), Coastal karst landforms. Springer, Dordrecht, p. 347-374.

https://doi.org/10.1007/978-94-007-5016-6 16

Karaman S.L., 1954 - Über unsere unterirdische Fauna. Acta Musei Macedonici Scientiraum Naturalium, 1: 195-216.

Kelber A., Balkenius A. \& Warrant E.J., 2002 - Scotopic colour vision in nocturnal hawkmoths. Nature, 419: 922-925. https://doi.org/10.1038/nature01065

Longley G., 1984 - The Edwards Aquifer: the most diverse groundwater ecosystem? International Journal of Speleology, 11: 123-128.

https://doi.org/10.5038/1827-806X.11.1.12

Malard F., Ward J.V. \& Robinson C.T., 2000-An expanded perspective of the hyporheic zone. Verhaltlungen der Internationalen Vereinigung für Theoretische und Angewandte Limnologie, 27: 431-437.

https://doi.org/10.1080/03680770.1998.11901268

Mejia-Ortíz L.M., 2005 - Adaptations to cave life in decapods from Oaxaca. Bulletin of the Association for Mexican Cave Studies, 15: 1-169.

Mejía-Ortíz L.M., López-Mejía M., Sprouse P., 2013 Distribución de los crustáceos estigobiontes de México. Mundos Subterráneos, 24: 20-32.

Moseley M., 2009 - Are all caves ecotones? Cave and Karst Science, 36: 53-58.

Mylroie J.E. \& Mylroie J.R., 2007 - Development of the carbonate island karst model. Journal of Cave and Karst Studies, 69: 59-75.

Mylroie J.E., 2013 - Costal karst development in carbonate rocks. In: Lace M.J. \& Mylroie J.E. (Eds.), Coastal karst landforms. Springer, Dordrecht, p. 77-110. https://doi.org/10.1007/978-94-007-5016-6 4

Palacios-Vargas J.G., Juberthie C. \& Reddell J.R., 2014 2015 - México. Mundos Subterráneos, 25-26: 1-101.

Pipan T. \& Culver D.C., 2012 - Convergence and divergence in the subterranean realm: a reassessment. Biological Journal of the Linnean Society, 107: 1-14. https://doi.org/10.1111/j.1095-8312.2012.01964.x

Pipan T. \& Culver D.C., 2012 - Shifting paradigms of the evolution of cave life. Acta Carsologica, 44: 415-425.

Pipan T., López H., Oromí P., Polak S. \& Culver D.C., 2011 - Temperature variation and the presence of troglobionts in shallow subterranean habitats. Journal of Natural History, 45: 253-273.

https://doi.org/10.1080/00222933.2010.523797

Poulson T.L., 1963 - Cave adaptation in amblyopsid fishes. American Midland Naturalist, 70: 257-290. https://doi.org/10.2307/2423056

Poulson T.L.\& Culver D.C., 1969 - Diversity in terrestrial cave communities. Ecology, 50: 153-158. https:/ / doi.org/10.2307/1934678

Prendini L., Francke O.F. \& Vignoli V., 2010 Troglomorphism, trichobothriotaxy and typhlochactid phylogeny (Scorpiones, Chactoidea): more evidence that troglobitism is not an evolutionary dead end. Cladistics, 26: 117-142.

https://doi.org/10.1111/j.1096-0031.2009.00277.x

Pulliam H.R., 1988 - Sources, sinks, and population regulation. American Naturalist, 132: 652-661. https://doi.org/10.1086/284880

QRSS, 2017 - Quintana Roo Speleological Survey. (accessed: March 20, 2017). https://caves.org/project/qrss/qrss.htm

Racovitza E.G., 1907 - Essai sur les problèmes biospéologiques. Archives de Zoologie Expérimentale et Générale, 6: 371-488.

Reddell J.R., 1981 - A review of the cavernicole fauna of Mexico, Guatemala, and Belize. Austin: Texas Memorial Museum Bulletin, 27: 1-327.

Rouch R., 1968 - Contribution à la connaissance des harpactiicides hypogés (Crustacés-Copepodes). Annales de Spéléologie, 23: 5-167.

Růžička V., 1990 - The spiders of stony debris. Acta Zoologica Fennica, 190: 333-337.

Spaw R.H., 1978 - Late Pleistocene carbonate bank deposition: Cozumel Island, Quintana Roo, Mexico. Transactions of the Gulf Coast Association of Geological Studies, 28: 601-619.

Taylor S.J., Krecja J.K., Slay M.E. \& Harrison T.L., 2009 - Milbert's tortoiseshell, Aglais milberti (Lepidoptera: Numphalidae): facultative trogloxene in alpine caves. Speleobiology Notes, 1: 20-23.

Tierney S.M., Friedrich M., Humphreys W.F., Jones T.M., Warrant E.J. \& Weiso W.T., 2017 - Consequences of evolutionary transitions in changing photic environments. Australian Entomology, 51: 23-46. https://doi.org/10.1111/aen.12264

Trajano E. \& de Carvalho M.R. 2017 - Towards a biologically meaningful classification of subterranean organisms: a critical analysis of the Schiner-Racovitza system from a historical perspective, difficulties of its application and implications for conservation. Subterranean Biology, 22: 1-26.

https://doi.org/10.3897/subtbiol.22.9759

Warrant, EJ. Invertebrate vision in dim light. In: Warrant E.J. \& Nilson D.E. (Eds.), Invertebrate vision. Cambridge University Press, Cambridge, p. 83-126. 